\title{
Chalcogen-Containing Oxazolines in the Palladium-Catalyzed Asymmetric Allylic Alkylation
}

\author{
Antonio L. Braga, * Diogo S. Lüdtke and Eduardo E. Alberto \\ Departamento de Química, Universidade Federal de Santa Maria, 97105-900, Santa Maria-RS, Brazil
}

\begin{abstract}
Nesse trabalho descreve-se, pela primeira vez, um estudo comparativo sobre a atuação de oxazolinas quirais contendo calcogênio em suas estruturas em reação de alquilação alílica assimétrica, catalisada por paládio, do acetato de 1,3-difenil-2-propenila com malonato de dimetila. Diferenças no desempenho entre os análogos de enxofre, selênio e telúrio são observadas.
\end{abstract}

A comparative study about the ability of chiral chalcogen-containing oxazolines to act as chiral ligands in the palladium-catalyzed allylic alkylation of rac-1,3-diphenyl-2-propenyl acetate with dimethyl malonate is reported. Differences in the catalytic performance are observed with sulfur, selenium and tellurium analogues.

Keywords: selenium, oxazolines, palladium, asymmetric allylic alkylation, tellurium

\section{Introduction}

The search for new ligands in asymmetric catalysis is a field of continuing interest. To facilitate practical applications, new ligands should be easy to prepare from simple and easily available starting materials.

In this context, the use of chiral nitrogen compounds bearing an organochalcogen moiety and their metal complexes have gained increased importance in the field of asymmetric catalysis due to their novel and unprecedented properties. For example, they have been reported to be efficient chiral catalysts ${ }^{1}$ in several different enantioselective reactions, such as the asymmetric hydrosilylation $^{2}$ and hydrogenation ${ }^{3}$ of ketones, enantioselective diethylzinc ${ }^{4},{ }^{5}$ and alkynylzinc ${ }^{6}$ addition to aldehydes, and conjugate addition of organocopper reagents to to enones.?

Among the transition metal-catalyzed reactions known to form carbon-carbon and carbon-heteroatom bonds, the palladium-catalyzed allylic substitution stands out as one of the most valuable synthetic tools available. ${ }^{8}$ Many sulfur-containing ligands have been described to catalyze this transformation in an asymmetric fashion. ${ }^{9}$ On the other hand, the parent selenium-containing ligands for asymmetric allylations have been largely overlooked. ${ }^{10}$ Furthermore, to the best of our knowledge, tellurium-

* e-mail: albraga@quimica.ufsm.br containing analogues have never been tested in such transformation.

In this paper we report about the examination on the behavior of a series of sulfur- selenium- and telluriumcontaining oxazolines as chiral catalysts for the asymmetric alkylation of racemic 1,3-diphenyl-2-propenyl acetate with dimethylmalonate, catalyzed by palladium. ${ }^{11}$

\section{Results and Discussion}

The chiral chalcogeno-oxazolines were synthesized in two different approaches. The first one starts from amino acids S-benzyl- $L$-Cysteine and $L$-methionine. Initially, both amino acids were cleanly reduced with the $\mathrm{NaBH}_{4} / \mathrm{I}_{2}$ method, ${ }^{12}$ to afford thioether amino alcohol $\mathbf{1}$ and $\mathbf{3}$ in good yields. The amino alcohol moiety was then cyclized in good yields to their corresponding oxazolines $\mathbf{2}$ and $\mathbf{4}$ by reaction with ethyl chlorobenzimidate in boiling 1,2-dichloroethane, with $\mathrm{K}_{2} \mathrm{CO}_{3}$ as base (Scheme 1).

The second approach employs $L$-aspartic acid as the chiral source. Ligands 8a-c were obtained by esterification of both carboxyl groups of $L$-aspartic acid, followed by acylation at nitrogen with benzoyl chloride. The diester was cleanly reduced to the diol $6^{13}$ which was treated, without further purification, with $\mathrm{TsCl}$ in dichloromethane using triethylamine as base. The ditosylated intermediate immediately cyclizes to the entropically favored oxazoline 7. The organochalcogen functionalization took place by nucleophilic displacement of the tosylate leaving group 
<smiles>[Z6]C(C)OC1=N[C@@H](CSCc2ccccc2)CO1</smiles>
S-Bn-L-cysteine

$181 \%$ $275 \%$

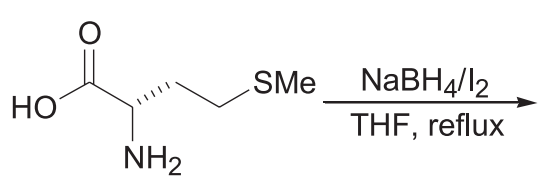

L-methionine<smiles>CSCC[C@H](N)CO</smiles>

$389 \%$

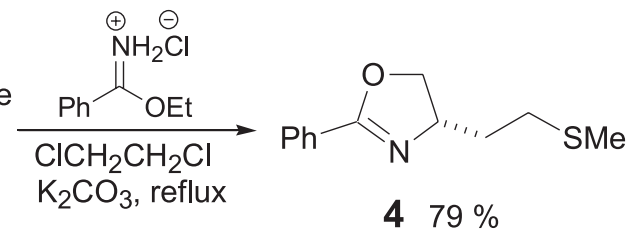

$479 \%$
Scheme 1.

by a phenyl chalcogenide anion generated by reduction of the corresponding diphenyl dichalcogenide with $\mathrm{NaBH}_{4}$ in a 3:1 mixture of THF and ethanol. The desired chalcogeno-oxazolines 8a-c were obtained with yields ranging from $72-97 \%$ (Scheme 2). ${ }^{14}$

With ligands 2, $\mathbf{4}$ and 8a-c in hands, we turned our attention to investigate their potential in the palladiumcatalyzed asymmetric allylic alkylation.

It is worth to mention that ligand $\mathbf{8 b}$ has already been reported by our group to act as efficient chiral catalyst for this asymmetric allylation reaction. ${ }^{15}$ We the carried out a comparative study on the alkylation reaction of racemic 1,3-diphenyl-2-propenyl acetate with dimethyl malonate, using the chiral chalcogen-containing oxazolines as chiral ligands $(10 \mathrm{~mol} \%)$ in the presence of $\left[\mathrm{Pd}\left(\eta^{3}-\mathrm{C}_{3} \mathrm{H}_{5}\right) \mathrm{Cl}\right]_{2}$ $(2.5 \mathrm{~mol} \%)$. Several different conditions were screened, and variations were made in the base, solvent and temperature. The results of these studies are summarized in Table 1.

We have first evaluated ligand $\mathbf{2}$ and $\mathbf{4}$ as catalysts in the asymmetric allylation, under conditions first described by Williams and coworkers, ${ }^{16}$ that uses NaH/THF as the base/solvent system. Moderate enantioselection was achieved with ligand $\mathbf{2}$, while ligand $\mathbf{4}$ furnished the product in higher level of enantioselection. We then decided to study further variations in the reaction setup, especially concerning the base/solvent combination and the temperature of the reaction. Initially, temperature was decreased to $0{ }^{\circ} \mathrm{C}$ and the product was obtained in the same ee compared to the room temperature reaction. Changing the base to BSA/KOAc and the solvent to dichloromethane did not result in any improvement in the ee, not even when the reaction was carried out at lower temperatures. At $-78{ }^{\circ} \mathrm{C}$ no reaction at all was observed (See entries 4-6).

We then decided to evaluate the behavior of catalysts 4 and $\mathbf{8 a - c}$ under conditions previously developed by us for seleno-oxazoline $\mathbf{8 b}\left(\mathrm{Cs}_{2} \mathrm{CO}_{3} / \mathrm{CH}_{2} \mathrm{Cl}_{2}\right) \cdot{ }^{17}$ This would allow us to make a direct comparison of the ability of sulfur, selenium and tellurium to complexate with palladium and to catalyze the asymmetric allylation reactions. Seleniumcontaining oxazoline $\mathbf{8 b}$ has proven to be the more efficient

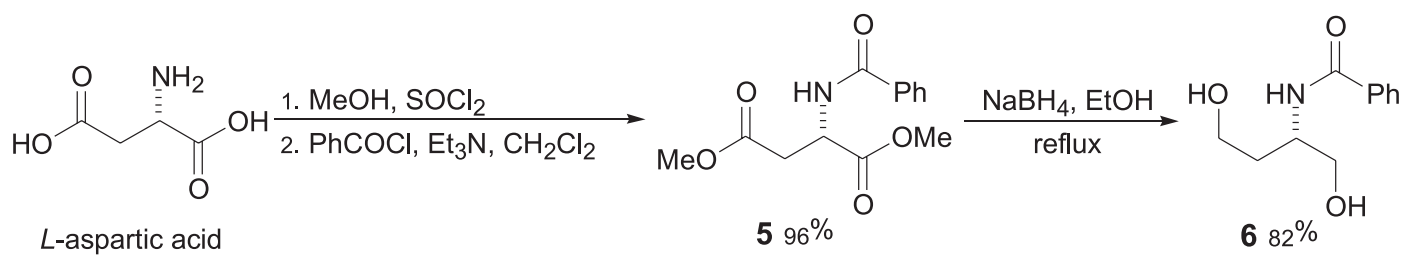
5 96\%<smiles></smiles>

8a $Y=S, 84 \%$

$8 \mathbf{b} Y=\mathrm{Se}, 97 \%$

8c $Y=T e, 72 \%$
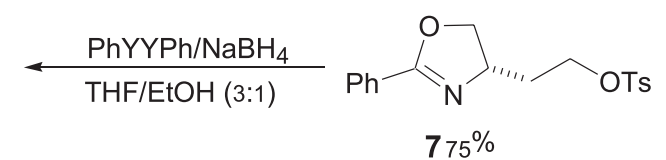

Scheme 2. 
of the series, delivering the product 9 in $91 \%$ ee, when the reaction was carried out at $0{ }^{\circ} \mathrm{C}$ (Entry 10). The sulfur derivatives $\mathbf{4}$ and $8 \mathrm{a}$ furnished the alkylated product in 82 and $83 \% e e$, respectively, under the optimal conditions (Entries 7 and 8). This observation of difference in the behavior between sulfur and selenium donors gives an evidence of the higher ability of selenium to complexate with palladium and thus to form a tighten complex that would lead to a superior level of enantioselection.

To the best of our knowledge, a chiral organic telluride was never evaluated as a chiral ligand for this kind of transformation. We then tested the telluro-oxazoline 8c as catalyst in the alkylation reaction, but unfortunately, no reaction was observed and the decomposition of the palladium complex was observed, which could be evidenced by the formation of palladium black in the reaction medium. A possible explanation for this could be that the palladium could be inserted into the $\mathrm{Csp}^{2}-\mathrm{Te}$ bond, leading to the decomposition of the catalyst. This proposal is supported by the fact that unsaturated organic tellurides can undergo cross-coupling reactions with several nucleophiles, in the presence of palladium catalysts. $^{18}$

In order to propose a plausible explanation of the stereoselectivity observed, a schematic reaction pathway is shown in Scheme 3.

The attack of the nucleophile in a $\pi$-allylpalladium complex is believed to take place trans to the better $\pi^{-}$ acceptor. Supported by the work of Anderson where he proposes that the attack of the nucleophile occurs trans to a nitrogen donor $^{9}$ in a nitrogen-sulfur chelate complex, we assumed that our system behaves in a similar way,
Table 1.

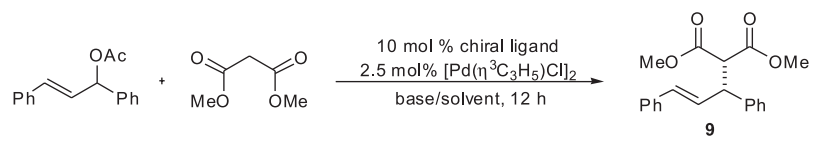

\begin{tabular}{lcccccc}
\hline Entry Ligand & Base & Solvent & $\begin{array}{c}\text { Temp. } \\
\left({ }^{\circ} \mathrm{C}\right)\end{array}$ & $\begin{array}{c}\text { Yield } \\
(\%)^{a}\end{array}$ & $\begin{array}{c}e e \\
(\%)^{b}\end{array}$ \\
\hline 1 & $\mathbf{2}$ & $\mathrm{NaH}$ & $\mathrm{THF}$ & $\mathrm{rt}$ & 90 & 76 \\
2 & $\mathbf{4}$ & $\mathrm{NaH}$ & $\mathrm{THF}$ & $\mathrm{rt}$ & 93 & 84 \\
3 & $\mathbf{4}$ & $\mathrm{NaH}$ & $\mathrm{THF}$ & 0 & 87 & 84 \\
4 & $\mathbf{4}$ & $\mathrm{BSA} / \mathrm{KOAc}$ & $\mathrm{CH}_{2} \mathrm{Cl}_{2}$ & $\mathrm{rt}$ & 93 & 75 \\
5 & $\mathbf{4}$ & $\mathrm{BSA} / \mathrm{KOAc}$ & $\mathrm{CH}_{2} \mathrm{Cl}_{2}$ & 0 & 65 & 77 \\
6 & $\mathbf{4}$ & $\mathrm{BSA} / \mathrm{KOAc}^{2}$ & $\mathrm{CH}_{2} \mathrm{Cl}_{2}$ & -78 & $\mathrm{nr}$ & $\mathrm{nr}$ \\
7 & $\mathbf{4}$ & $\mathrm{Cs}_{2} \mathrm{CO}_{3}$ & $\mathrm{CH}_{2} \mathrm{Cl}_{2}$ & 0 & 95 & 83 \\
8 & $\mathbf{8 a}$ & $\mathrm{Cs}_{2} \mathrm{CO}_{3}$ & $\mathrm{CH}_{2} \mathrm{Cl}_{2}$ & 0 & 88 & 82 \\
9 & $\mathbf{8 b}$ & $\mathrm{Cs}_{2} \mathrm{CO}_{3}$ & $\mathrm{CH}_{2} \mathrm{Cl}_{2}$ & $\mathrm{rt}$ & 99 & 85 \\
10 & $\mathbf{8 b}$ & $\mathrm{Cs}_{2} \mathrm{CO}_{3}$ & $\mathrm{CH}_{2} \mathrm{Cl}_{2}$ & 0 & 99 & 91 \\
11 & $\mathbf{8 c}$ & $\mathrm{Cs}_{2} \mathrm{CO}_{3}$ & $\mathrm{CH}_{2} \mathrm{Cl}_{2}$ & $\mathrm{rt}$ & $\mathrm{nr}$ & $\mathrm{nr}$ \\
\hline
\end{tabular}

${ }^{a}$ Isolated yields. ${ }^{b}$ Determined by HPLC with a Daicel Chiralcel OD column, hexane:isopropanol 99:1;0.5 $\mathrm{mL} \mathrm{min}^{-1} ; 254 \mathrm{~nm}$.

i.e., the nucleophile attacks preferentially at the allylic position trans to the Pd-N bond in the $\pi$-allylpalladium complex.

Since the major product obtained is the $(R)-\mathbf{9}$, the reaction appears to proceed preferentially via the intermediate (A) in the equilibrium depicted in Scheme 3. Intermediate (A), where the allyl group is disposed in a "W" orientation, seems to be more stable than intermediate (B), where the allyl moiety is arranged in a "M" conformation. The major interaction that accounts for the difference in the stability of both intermediates would be the steric repulsion between the phenyl terminus of the allylic substrate and the phenyl group of the 2-oxazoline ring, in intermediate (B). This disfavoring interaction would

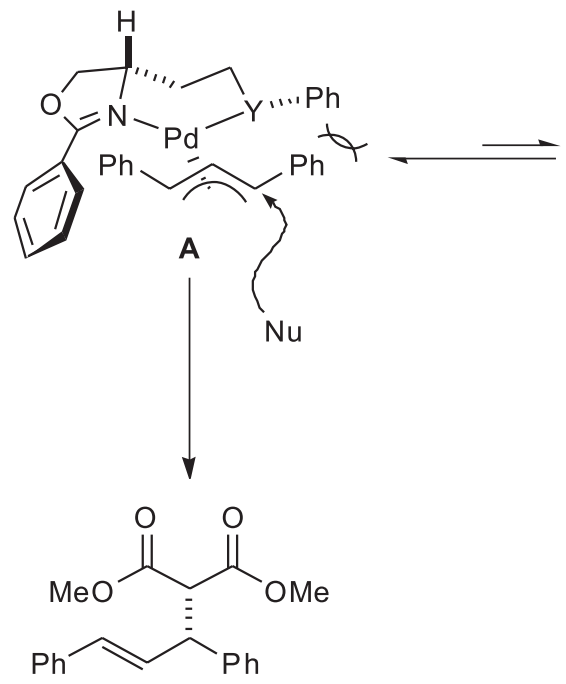

(R)-9

major product

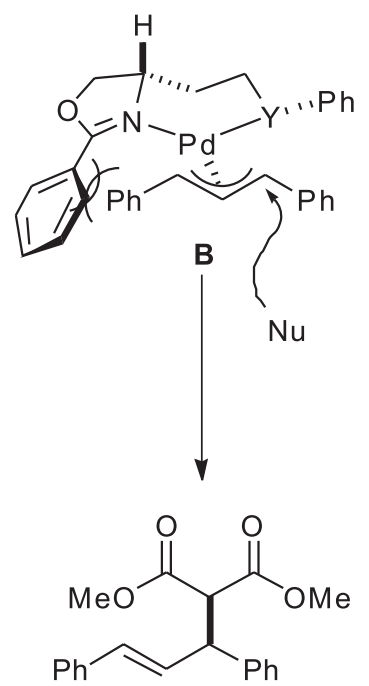

(S) -9

Scheme 3. 
explain the predominance of intermediate (A) in the equilibrium.

Indeed, attack of the nucleophile at the allyl moiety trans to the nitrogen atom in structure (A) would lead to the $(R)-9$ product, which is in full agreement with the observed in the reaction.

\section{Conclusions}

In summary, we have described a study were a set of chalcogeno-oxazolines have been synthesized in a short, high yielding synthetic route and with a modular character. Furthermore, these compounds were tested as chiral ligands for the palladium-catalyzed allylation of racemic 1,3-diphenyl-2-propenyl acetate with dimethylmalonate. Good to high ees of up to $91 \%$ of the product were achieved. The best result was obtained with the selenooxazoline 8b, compared to the sulfur and tellurium analog. This result demonstrates the higher ability of selenium to complexate with palladium and thus, is an interesting feature that should be taken into consideration for the design of new ligands containing the chalcogen atom.

\section{Acknowledgments}

The authors gratefully acknowledge CAPES, CNPq and FAPERGS for financial support. CAPES is also acknowledged for providing a $\mathrm{PhD}$ fellowship to D.S.L.

\section{References}

1. For a review concerning chiral thioether ligands in asymmetric catalysis, see: Madeu-Bulto, A. M.; Dieguez, M.; Martin, M.; Gomez, M.; Coord. Chem. Rev. 2003, 242, 159; For reviews about organoselenium chemistry in stereoselective synthesis, see Wirth, T.; Tetrahedron 1999, 55, 1; Wirth, T.; Angew. Chem., Int. Ed. 2000, 39, 3740; Wirth, T.; Topics in Current Chemistry: Organoselenium Chemistry, Modern Developments in Organic Synthesis; Wirth, T., ed.; Springer: Berlin, Germany, 2000; For a recent paper on the synthesis of chiral seleniumcontaining amino acid derivatives and peptides, see: Braga, A. L.; Lüdtke, D. S.; Paixão, M. W.; Alberto, E. E.; Stefani, H. A.; Juliano, L.; Eur. J. Org. Chem. 2005, 4260.

2. Nishibayashi, Y.; Singh, J. D.; Segawa, K.; Fukuzawa, S. -I.; Uemura, S.; J. Chem. Soc., Chem. Commun. 1994, 1375; Nishibayashi, Y.; Segawa, K.; Singh, J. D.; Fukuzawa, S. -I.; Ohe, K.; Uemura, S.; Organometallics 1996, 15, 370.

3 . Gayet, A.; Bolea, C.; Andersson, P. G.; Org. Biomol. Chem. 2004, 2, 1887; Harfouche, J.; Herault, D.; Tommasino, M. L.; Pellet-Rostaing, S.; Lemaire, M.; Tetrahedron: Asymmetry 2004, 15, 3413.
4. Wirth, T.; Tetrahedron Lett. 1995, 36, 7849; Wirth, T.; Kulieke, K. J.; Fragale, G.; Helv. Chim. Acta 1996, 79, 1957; Santi, C.; Wirth, T.; Tetrahedron: Asymmetry 1999, 10, 1019; Braga, A. L.; Rodrigues, O. E. D.; Paixão, M. W.; Appelt, H. R.; Silveira, C. C.; Bottega, D. P.; Synthesis 2002, 2338; Braga, A. L.; Paixão, M. W.; Lüdtke, D. S.; Silveira, C. C.; Rodrigues, O. E. D.; Org. Lett. 2003, 5, 2635.

5. Anderson, J. C.; Cubbon, R.; Harding, M.; James, D. S.; Tetrahedron: Asymmetry 1998, 9, 3461; Gibson, C. L.; Chem. Commun. 1996, 645; Eriksen, H. S.; Oyaga, S. C.; Sherrington, D. C.; Gibson, C. L.; Synlett 2005, 1235; Braga, A. L.; Appelt, H. R.; Schneider, P. H.; Silveira, C. C.; Wessjohann, L. A.; Tetrahedron: Asymmetry 1999, 10, 1733; Braga, A. L.; Lüdtke, D. S.; Wessjohann, L. A.; Paixão, M. W.; Schneider, P. H.; J. Mol. Catal. A: Chem. 2005, 229, 47.

6. Braga, A. L.; Appelt, H. R.; Silveira, C. C.; Wessjohann, L. A.; Schneider, P. H.; Tetrahedron 2002, 58, 10413.

7. Zhou, Q. -L.; Pfaltz, A.; Tetrahedron 1994, 50, 4467; Lambert, F.; Knotter, D. M.; Janssen, M. D.; van Klaveren, M.; Boersma, J.; van Koten, G.; Tetrahedron: Asymmetry 1991, 2, 1097; Cran, G. A.; Gibson, C. L.; Handa, S.; Kennedy, A. R.; Tetrahedron: Asymmetry 1996, 7, 2511; Nakagawa, Y.; Kanai, M.; Nagaoka, Y.; Tomioka, K.; Tetrahedron Lett. 1996, 37, 7805; Dieter, R. K.; Tokles, M.; J. Am. Chem. Soc. 1987, 109, 2040; Braga, A. L.; Silva, S. J. N.; Lüdtke, D. S.; Drekener, R. L.; Silveira, C. C.; Rocha, J. B. T.; Wessjohann, L. A.; Tetrahedron Lett. 2002, 43, 7329.

8. Tsuji, J.; Palladium Reagents and Catalysis, Innovations in Organic Synthesis, Wiley: New York, 1995; Trost, B. M.; Van Vranken, D. L.; Chem. Rev. 1996, 96, 395; Helmchen, G.; Kudis, S.; Sennhenn, P.; Steinhagen, H.; Pure Appl. Chem. 1997, 69, 513; Johannsen, M.; Jorgensen, K. A.; Chem. Rev. 1998, 98, 1689; Hayashi, T.; J. Organomet. Chem. 1999, 576, 195; Helmchen, G.; J. Organomet. Chem. 1999, 576, 203; Trost, B. M.; Lee, C.; Catalytic Asymmetric Synthesis, 2nd ed.; Ojima, I., ed.; Wiley-VCH: New York, 2000; Ch. 8E, pp 503-650; Trost, B. M.; Crawley, M. L.; Chem. Rev. 2003, 103, 2921; Trost, B. M.; J. Org. Chem. 2004, 69, 5813.

9. Frost, C. G.; Williams, J. M. J.; Tetrahedron: Asymmetry 1993, 4, 1785; Allen, J. V.; Bower, J. F.; Williams, J. M. J.; Tetrahedron: Asymmetry 1994, 5, 1895; Allen, J. V.; Coote, S. J.; Dawson, G. J.; Frost, C. G.; Martin, C. J.; Williams, J. M. J.; J. Chem. Soc., Perkin Trans. 1 1994, 2065; Chesney, A.; Bryce, M. R.; Chubb, R. W.; Batsanov, A. S.; Howard, J. A.; Tetrahedron: Asymmetry 1997, 8, 2337; Adams, H.; Anderson, J. C.; Cubbon, R.; James, D. S.; Mathias, J. P.; J. Org. Chem. 1999, 64, 8256; Chelucci, G.; Muroni, D.; Saba, A.; Soccolini, F.; J. Mol. Catal. A: Chem. 2003, 197, 27; Selvakumar, K.; Valentini, M.; Pregosin, P. S.; Organometallics 1999, 18, 4591; Kang, J.; Lee, J. H.; Im, K. S.; J. Mol. Catal. A: Chem. 2003, 196, 55. 
10. Sprinz, J.; Kiefer, M.; Helmchen, G.; Reggelin, M.; Huttner, G.; Walter, O.; Zsolnai, L.; Tetrahedron Lett. 1994, 35, 1523; Hiroi, K.; Suzuki, Y.; Abe, I.; Tetrahedron: Asymmetry 1999, 10, 1173; You, S. -L.; Hou, X. -L.; Dai, L. -X.; Tetrahedron: Asymmetry 2000, 11, 1495; Hou, X. -L.; Wu, X. -W.; Dai, L.X.; Cao, B. -X.; Sun, J.; Chem. Commun. 2000, 1195.

11. For previous reports of our group in palladium-catalyzed asymmetric allylic alkylations, see: Schneider, P. H.; Schrekker, H. S.; Silveira, C. C.; Wessjohann, L. A.; Braga, A. L.; Eur. J. Org. Chem. 2004, 2715; Braga, A. L.; Paixão, M. W.; Milani, P.; Silveira, C. C.; Rodrigues, O. E. D.; Alves, E. F.; Synlett 2004, 1297; Braga, A. L.; Sehnem, J. A.; Lüdtke, D. S.; Zeni, G.; Silveira, C. C.; Marchi, M. I.; Synlett 2005, 1331; Braga, A. L.; Paixão, M. W.; Marin, G. Synlett 2005, 1675; Braga, A. L.; Silveira, C. C.; de Bolster, M. W. G.; Schrekker, H. S.; Wessjohann, L. A.; Schneider, P. H.; J. Mol. Catal. A: Chem. 2005, 239, 235; Braga, A. L.; Vargas, F.; Sehnem, J. A.; Braga, R. C.; J. Org. Chem. 2005, 70, in press.

12. McKennon, M. J.; Meyers, A. I.; Drauz, K.; Schwarm, M.; J. Org. Chem. 1993, 58, 3568.

13. Ksander, G. M.; de Jesus, R.; Yuan, A.; Ghai, R. D.; Trapani, A.; McMartin, C.; Bohacek, R.; J. Med. Chem. 1997, 40, 495.

14. General procedure for the preparation of 8 : Under an argon atmosphere, sodium borohydride was added to a solution of the diphenyl dichalcogenide $(0.55 \mathrm{mmol})$ in THF $(4 \mathrm{~mL})$. Ethanol $(2 \mathrm{~mL})$ was then dropwise added and the clear solution formed was stirred at room temperature for 10 minutes. After this time a THF (1 mL) solution of the appropriate oxazolinyl tosylate $(1 \mathrm{mmol})$ was added dropwise. After stirring for $24 \mathrm{~h}$ at room temperature, the reaction mixture was quenched with aqueous saturated $\mathrm{NH} 4 \mathrm{Cl}(10 \mathrm{~mL})$ and extracted with $\mathrm{CH}_{2} \mathrm{Cl}_{2}$ $(3 \times 15 \mathrm{~mL})$. The combined organic layers were dried with $\mathrm{MgSO}_{4}$, filtered and concentrated. The crude product was purified by flash chromatography first eluting with hexanes and then with a mixture of hexanes/ethyl acetate (80:20). Selected spectral and analytical data for $(S)$-2-phenyl-4-(2(phenylthio)ethyl)-4,5-dihydrooxazol (8a). Yield: $84 \%$; $[\alpha]_{\mathrm{D}}^{20}=-26\left(c=0.55, \mathrm{CH}_{2} \mathrm{Cl}_{2}\right) ; 1 \mathrm{H} \mathrm{NMR}\left(\mathrm{CDCl}_{3}, 400 \mathrm{MHz}\right)$ : $\delta$ 7.95-7.93 (m, 2H), 7.41-7.11 (m, 8H), 4.42-4.36 (m, 2H), 3.95-3.92 (m, 1H), 3.13-3.11 (m, 1H), 3.05-3.02 (m, 1H), 1.5$1.87(\mathrm{~m}, 2 \mathrm{H}) ;{ }^{13} \mathrm{C} \mathrm{NMR}\left(\mathrm{CDCl}_{3}, 100 \mathrm{MHz}\right): \delta 163.47,136.07$, 131.06, 128.75, 128.65, 128.02, 128.00, 127.47, 125.62, 72.03, 65.44, 35.26, 29.80; HRMS m/z Calc. for $\mathrm{C}_{17} \mathrm{H}_{18} \mathrm{ONS}^{+} \mathrm{H}^{+}$ 284.1107, Found 284.1103.

(S)-2-phenyl-4-(2-(phenylselanyl)ethyl)-4,5-dihydrooxazole (8b). Yield: $97 \%$; $[\alpha]_{\mathrm{D}}^{20}=-57\left(c=0.55, \mathrm{CH}_{2} \mathrm{Cl}_{2}\right) ;{ }^{1} \mathrm{H} \mathrm{NMR}$
$\left(\mathrm{CDCl}_{3}, 400 \mathrm{MHz}\right): \delta 7.93(\mathrm{~d}, J 7.16 \mathrm{~Hz}, 2 \mathrm{H}), 7.52-7.37$ (m, 5H), 7.26-7.20 (m, 3H), 4.48-4.37 (m, 2H), 4.02-3.98 (m, 1H), 3.14-2.99 (m, 2H), 2.10-2.01 (m, 1H), 2.00-1.94 (m, 1H); ${ }^{13} \mathrm{C} \mathrm{NMR}\left(\mathrm{CDCl}_{3}, 100 \mathrm{MHz}\right): \delta 165.88,132.48,131.24,130.04$, 129.14, 128.21, 128.17, 127.99, 126.74, 72.12, 66.46, 36.45, 24.04; HRMS $m / z$ Calc. for $\mathrm{C}_{17} \mathrm{H}_{17} \mathrm{ONSe}^{+} \mathrm{Na}^{+} 354.0366$; Found 354.0367.

(S)-2-phenyl-4-(2-(phenyltelanyl)ethyl)-4,5-dihydrooxazol $(8 c)$. Yield: $72 \% ;[\alpha]_{\mathrm{D}}^{20}=-63\left(c=0.5, \mathrm{CH}_{2} \mathrm{Cl}_{2}\right) ;{ }^{1} \mathrm{H} \mathrm{NMR}\left(\mathrm{CDCl}_{3}\right.$, $400 \mathrm{MHz}): \delta 7.93(\mathrm{~d}, J 7.2 \mathrm{~Hz}, 2 \mathrm{H}), 7.72(\mathrm{~d}, J 6.9 \mathrm{~Hz}, 2 \mathrm{H})$; 7.45-7.36 (m, 3H), 7.25-7.16 (m, 3H), 4.45-4.35 (m, 1H), 4.33$4.31(\mathrm{~m}, 1 \mathrm{H}), 4.00-3.96(\mathrm{~m}, 1 \mathrm{H}), 3.12-3.05(\mathrm{~m}, 1 \mathrm{H}), 2.98-2.91$ (m, 1H), 2.17-2.11 (m, 2H); ${ }^{13} \mathrm{C}$ NMR ( $\left.\mathrm{CDCl}_{3}, 100 \mathrm{MHz}\right): \delta$ $163.71,138.05,131.26,129.10,128.22,127.63,127.48$, 126.79, 112.44, 71.98, 68.14, 38.05, 4.44; HRMS m/z Calc. for $\mathrm{C}_{17} \mathrm{H}_{17} \mathrm{ONTe}^{+} \mathrm{H}^{+}$398.0392; Found 398.0394.

15. Braga, A. L.; Lüdtke, D. S.; Sehnem, J. A.; Alberto, E. E.; Tetrahedon 2005, 61, in press.

16. Dawson, G. J.; Frost, C. G.; Martin, C. J.; Williams, J. M. J.; Tetrahedron Lett. 1993, 34, 7793.

17. General Procedure for the Asymmetric Allylic Alkylation with $\mathrm{Cs}_{2} \mathrm{CO} / \mathrm{CH}_{2} \mathrm{Cl}_{2}$ : A solution of $\left[\mathrm{Pd}\left(\mathrm{h}_{3}-\mathrm{C}_{3} \mathrm{H}_{5}\right) \mathrm{Cl}\right]_{2}(10 \mathrm{mg}, 2.5$ $\mathrm{mol} \%)$, catalyst $(10 \mathrm{~mol} \%)$ in dichloromethane $(2.5 \mathrm{~mL})$ was stirred for $1 \mathrm{~h}$ under an argon atmosphere, at room temperature, and then cooled to $0{ }^{\circ} \mathrm{C}$, when 1,3-diphenyl-2-propenyl acetate (126 mg, $0.5 \mathrm{mmol}$ ) was added. The mixture was stirred for 10 minutes at this temperature and dimethyl malonate $(173 \mathrm{mg}$, $1.5 \mathrm{mmol}$ ), and cesium carbonate (489 $\mathrm{mg}, 1.5 \mathrm{mmol}$ ) were sequentially added. The reaction mixture was then stirred for $10 \mathrm{~h}$ at $0{ }^{\circ} \mathrm{C}$. After this time, saturated $\mathrm{NH}_{4} \mathrm{Cl}_{\text {(aq) }}$ was added and the aqueous solution was extracted with $\mathrm{CH}_{2} \mathrm{Cl}_{2}(3 \times 15$ $\mathrm{mL}$ ). The combined organic layers were dried with $\mathrm{MgSO}_{4}$, the solvent was evaporated and the crude product was purified by flash chromatography eluting with hexane/ethyl acetate (98/ 2). Enantiomeric excess was determined by chiral HPLC (Chiralcel OD column, $0.5 \mathrm{~mL}$ min-1, hexane:2-propanol 99:1, $254 \mathrm{~nm}$ ). The optical rotation of the product was compared with literature data to assign the absolute configuration $(R)$.

18. Zeni, G.; Braga, A. L.; Stefani, H. A.; Acc. Chem. Res. 2003, 36, 731; See also: Raminelli, C.; Prechtl, M. H. G.; Santos, L. S.; Eberlin, M. N.; Comasseto, J. V.; Organometallics 2004, 23, 3990 .

Received: September 13, 2005 Published on the web: November 9, 2005 